いめまいとともに時計回り方向への回旋眼振が 発現する. めまい, 眼振は約 23 秒で治まるが, 正頭位に戻すと反時計回りの回旋眼振が出現す る。同じ検査を繰り返すとめまい，眼振は次第 に減弱し 4 回目には全く出現しない。温度反応 には左右差を認めない。聴力検査では両耳約 15 $\mathrm{dB}$ の水平型感音難聴を認めるがめまいとの関 連を認めない。素因検査では, 血圧正常, 血液 電解質, 総蛋白, 総コレステロール正常. $\beta$ リ ポプロテイン $861 \mathrm{ml} / \mathrm{dl}$ (正常值150〜 500), ト リグリセライド $226 \mathrm{ml} / \mathrm{dl}$ (正常值 76〜172).

良性発作性頭位性眩量症, 高中性脂肪血症が 素因と診断し，10月3日よりコレキサミン 6 錠, アプラクタン 3 カプセル, バランス $30 \mathrm{mg}$ を1 日量（3 回分服）として与兄，併せて週 1 回メイロン $40 \mathrm{ml}$ 注射を施行. 自覚症, 他覚所 見は次第に改善し，11月14日には頭位性めまい も訴光なくなり, 頭位眼振検査でもめまい, 眼 振を全く発来しない。ßリポプロテイン $760 \mathrm{ml}$ /d1,トリグリセライド $104 \mathrm{ml} / \mathrm{d} 1$ に減少。その 後, 食事の注意を与えているが症状は治まって いる。
本例の治療にはコレキサミン投与でトリグリ セライドを低下させたことが有效であったと考 兄られます。急激な発症, その後の頭位性めま いとトリグリセライド上昇を直ちに関連づける ことは問題もありますが, 強いて述べれば，年 令之高脂血症に伴ら血管異常が内耳循環不全を 特こし, その後遺症として卵形囊斑の感覚細胞 の変性を来し, 感覚細胞の興奮性の異常と高脂 血症による内耳循環不全が頭位性めまいを抏こ し、アプラクタンによる反射の抑制, コレキサ ミンによる血中脂質代謝異常の改善により症状 の改善を光たものと考光られます。

\section{III. おわりに}

原因不明の内耳性の頭位性めまいにどんな疾 患が含末机ているか，その成因は何か，めまい の反覆に対してどんな治療を行らべきか等多く の疑問がありますが，良性発作性頭位性眩量症 に対する私共のアプローチを述べました。

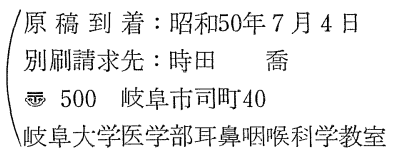

\title{
良性発作性頭位眩暈症の診断と病変部位
}

德增厚 二

\section{はじめに}

Dix, Hallpike らの報告による良性発作性頭 位眩暈症 Positional vertigo of benign paroxysmal type (以下 BPPV と略す) は蝸牛症 状を伴わない, 頭位あるいは頭位変換刺激で誘 発されるめまいと, 特徵的な眼振から診断の比 較的容易なめ屯い疾患の一つである。眼振の特 徵から脳血栓・脳出血に発展する脳血管障害,
脳腫瘍など重篤な頭位胘量症と区別される。

しかし頭位性純回旋性眼振の発現機序など病 態生理に関しては依然として明らかでない。

今回臨床的観察と眼振の出現理由について私 見をのべたい。

\section{臨 床 統 計}

北里大学病院での,めまい平衡障害例約 3,000 名のうち頭位眩暈症と診断したものは97名であ 
った。その中での BPPVは36例 $37.1 \%$ ある。

9 才より74才にわたり30才台が最も多く，30才 より59才迄は25例69.4\%。男女比は 5：7でや や女性に多かった。（表 1 ）

表 1 良性発作性頭位眩晕症の䛦断と病变部位

\begin{tabular}{|c|c|c|c|}
\hline Age $>$ Sex & Male & Female & Total \\
\hline under 9 & 1 & 0 & 1 \\
\hline $10 \sim 19$ & 0 & 1 & 1 \\
\hline $20 \sim 29$ & 1 & 2 & 3 \\
\hline $30 \sim 39$ & 4 & 9 & 13 \\
\hline $40 \sim 49$ & 2 & 4 & 6 \\
\hline $50 \sim 59$ & 3 & 3 & 6 \\
\hline $60 \sim 69$ & 3 & 1 & 4 \\
\hline over 70 & 1 & 1 & 2 \\
\hline Total & 15 & 21 & 36 \\
\hline
\end{tabular}

めまいは急に発生し, 突然消失するもの, 次 第に減弱し消失するもの, 消失迄 $2 \sim 3$ 月以上 比較的長期間要するもの, 一時改善して再発す るものなどがある。また永くめまい頭位に対し て強い不安を示すものがある。

薬物治療と同時に患者の不安感を除き，気分 の悪くならない程度に毎日めまい頭位を積極的 にとらせることが治癒を早めるように思われ る。

\section{診断基準}

1. 頭位で誘発される発作性回転性眩暈 ${ }^{11}$

2。聴覚症状はめまい発作に随伴しない

3。特徵西る眼振

1)純回旋性眼振が頭位,頭位変換検査で出現。

2)眼振はめまいに随伴。

3)眼振は潜伏時間をもって出現したのち漸次 減衰する。

4)頭位变換検查で体動方向が 逆の場合回旋 眼振の方向も逆転する（逆方向回旋性という Gegenläufigkeit)。

5)繰り返し誘発検査で眼振, めまいは減衰す る傾向がある。

4.中枢疾患を否定する

めまいは決して自発性に抗こることはない。
頸捻転に起因寸る頭位性眩暈や，自発性眩暈の 頭位，頭位変換による増強などと鑑別せねばな らない。蝸牛症状のめまい随伴がなく摳気，嘔 吐の自律神経症状も比較的稀である。

頭部非傾斜での自発回旋性眼振や方向固定性 の純回旋性眼振は BPPV ではなく中枢疾患の 可能性が高い。

純回旋性頭位眼振に混在して方向固定性水平 回旋性眼振を認めることがあるが両者は眼振の めまい随伴の有無で鑑別出来る。

\section{考察}

BPPV の病理所見は内耳の病变と報告されて (るる2)3)。

蝸牛症状を欠き, しかも水平回旋性眼振がな いことから少くとも蛤牛, 外側半規管を除いた 耳石器, 前・後半規管に限局した内耳部分障害 が推定される。

耳石器は頭位刺激の受容器で眼球偏位や眼球 反対回旋を和こし，また半規管性の眼振に影響 を与光るが，それのみで眼振を惹き起すかどう かは異論がある。

回旋性眼振は水平性眼振と同じく, 前庭性左 右不均衡を示すと考光られるので，32症例の BPPV の頭位，頭位変換眼振を次の方式に従っ て図1にまとめた。

矢状面での頭位変換検査で坐位より縣垂頭位
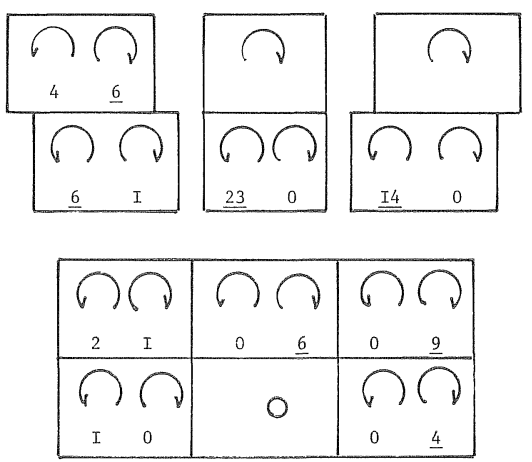

Positional and positioning rotary nystagmus in 32 cases of Positional Vertigo of Benign Paroxysmal Type. Each number means incidence of rotary nystagmus.

図 1 良性発作性頭位胘暈症の診断と病变部位 
へ倒した時への眼振はとのままとし，への時は これをへに改め同時にすべての眼振を鏡像とし て逆方向に改めた。この結果は我々の既発表の 結果と一致している( ${ }^{4) 5}$.

ここで BPPV の逆方向性純回旋性眼振の 発 現機序について次の仮説を提案したい。

「頭位変換による BPPV の逆方向性純回旋 性眼振は片側の前なたは後半規管の障害により 発現する」。

片側の前後両半規管から純回旋性眼振が生ず る。しかしこの場合には頭位変換で眼振方向が 逆転することはない。

左側後半規管単独の障害を仮定してみよう。 BPPVでは自発眼振がないから左後半規管と対 をなす右前半規管の反応性低下も予想される。 矢状面での頭位変換検査で坐位より懸垂頭位に 倒すと本来は両側の前半規管が刺激されるがこ の場合左前半規管のみの刺激でねの眼振がみら れる。逆に懸垂頭位から坐位に和こすと右後半 規管のみの刺激で凹の眼振が括こる。正常者で は頭位変換検査で両側前または後半規管が同時 に刺激されるにも拘わらず垂直眼振はみられな い。これは中枢抑制作用と理解されている。従 って先の場合垂直成分は消失し, 坐位より懸垂 頭位への刺激ではへの眼振があらわれ, 懸垂頭 位より坐位への刺激ではのの眼振が出現する。 すなわち逆方向回旋性眼振がみられるのである 5 .

一側難聴また温度検査で CP を示し且 BPPV 型眼振を示した症例について, 矢状面頭位変換 時坐位より懸垂頭位に倒すと患側へ向ら回旋性
眼振の出現することを既に報告した4)。

$\mathrm{BPPV}$ 剖検例で後半規管クプラに石灰化がみ られた Schuknecht の報告とも一致する。

一側前半規管の障害時にはこの関係は逆にな る筈である。

\section{まとめ}

良性発作性頭位昡暈症は頭位性に誘発される めまいで, めまいには純回旋性眼振が随伴す る。その診断に特徵的な頭位变換検査時の逆方 向性純回旋性眼振は一側の前あるいは後半規管 の障害から抗こるものであろらと推論した。

\section{参 考 文 献}

1) 北原正章, 吉本 裕 : めまい疾患の診断名, 診断 基準の標準化に括ける試案. 日本平衡神経学会第 26 回総会資料 p. 8, 昭和 45 年.

2) Schuknecht, H.F. : Positional vertigo : Clinical and experimental observation. Trans Amer Acad Ophthal Otolaryng. 66 : 319-332, 1962.

3) Harrison, M. S. : Benign positional vertigo. edited by Wolfson, R.J. : The vestibular system and its deseases. Univ. of Pennsylvania Press. 404-428, 1966.

4）德増厚二, 竹森節子: 眼振の回旋方向と病巣との 関係。Vestibular Research 25:73-74, 1969.

5）時田 喬：シンポジゥム・螖牛症状を欠く回転性 メマイ発作。Equilibrium Research 30 : p. 81, 1972.

\footnotetext{
/原稿 到 着: 昭和50年 7 月 2 日

別刷請求先 : 德増 厚二

齿 228 神奈川県相模原市麻溝台 1

北里大学医学部耳鼻喵喉科学教室
} 